\title{
Military Use in Public Security Operations: Is it ever Advisable?*
}

\section{David Pion-Berlin**}

\begin{abstract}
Countries throughout the Latin American region have introduced the armed forces into internal security operations of one kind or another. Since militaries are accustomed to using maximal levels of violence to defeat enemies, such interventions could pose threats to civilians. However, it may be that those risks vary, depending upon the nature of the intervention. Internal security challenges must first be disaggregated to explore the varieties of operations that militaries undertake. Militaries can adhere to this and other international human rights standards of behavior, when the requisites of the mission are compatible with their pre-existing skill sets. Where they are not, human rights violations will inevitably result. Evidence for this comes from research on counter-narcotic operations in Mexico where military police patrols are differentiated from high value targeted operations.
\end{abstract}

\section{KEY WORDS}

Military, military missions, military operations, police patrols, internal security, public security, Mexico, human rights.

\begin{abstract}
RESUMEN
Los paises de toda la región de América Latina han introducido a las fuerzas armadas en operaciones de seguridad interna de un o otro tipo. Dado que los militares están acostumbrados a utilizar niveles máximos de violencia para derrotar a los enemigos, tales intervenciones podrian representar una amenaza para los civiles. Sin embargo, puede ser que esos riesgos varien, dependiendo de la naturaleza de la intervención. Los desafios de seguridad interna primero se deben desagregar para explorar las variedades de operaciones que realizan los militares. Los militares pueden adherirse a esta y otras normas internacionales de comportamiento de derechos humanos, cuando los requisitos de la misión son compatibles con sus habilidades preexistentes. Donde no estén, inevitablemente se producirán violaciones de derechos humanos. La evidencia de esto proviene de la investigación sobre operaciones antinarcóticos en México, donde las patrullas de la policia militar se diferencian de las operaciones dirigidas de alto valor.
\end{abstract}

\section{PALABRAS CLAVE}

Militares, misiones militares, operaciones militares, patrullas policiales, seguridad interna, seguridad pública, México, derechos humanos.

*Artículo recibido el 30 de mayo de 2018 y aceptado para su publicación el 25 de junio de 2018

**Profesor en The University of California, Riverside, Estados Unidos. (david.pion@ucr.edu) orcid.org/ 0000-00029887-7083 


\section{SUMARIO}

1. Introduction

2. The Argument Against Military Use for Public Security

3. Disaggregating the Security Threat

4. Boundaries Between Police and Military Missions

5. The Mexican Case: Military Police Patrols vs. High Value Targeted Operations

6. Conclusion

\section{Introduction}

The use of armed forces personnel in internal security operations, and countercrime operations in particular, is now widespread in Latin America, for better or worse. The following statistics make the point:

- Guaranteeing the internal order is now a constitutional provision in ten Latin American nations. ${ }^{1}$

- In 2014, 94 percent of Latin American armed forces regularly performed operations related to public security, 65 percent have a program related to citizen security, and 76 percent possess regular programs for combatting drugs and crime. ${ }^{2}$

- 13 countries have military, counter crime, counter-narcotic operations. 14 countries have frontier operations against trans-border criminal activity, and 10 countries conduct military citizen security operations, including foot patrols, riot control and response to demonstrations. $^{3}$

Most scholars are deeply skeptical that soldiers can perform these roles competently and humanely. Specifically, they fret that the military will not be able to restrain their use of force, and that innocent civilians might get harmed in the process. For this reason, some nations have amended constitutions or passed laws restricting the use of military force within national borders. And yet, all nations of the region continue to allow for some form of military utilization under certain conditions.

\footnotetext{
1 "Comparative Atlas of Defense in Latin America and the Caribbean", Red de Seguridad y Defensa de América Latina, 2014. Disponible en: http://www.resdal.org/

2 "Comparative Atlas of Defense in Latin America and the Caribbean", Red de Seguridad y Defensa de América Latina, 2014. Disponible en: http://www.resdal.org/

3 "Comparative Atlas of Defense in Latin America and the Caribbean", Red de Seguridad y Defensa de América Latina, 2014. Disponible en: http://www.resdal.org/
} 
Does introducing the armed forces pose an unacceptable risk to these countries? Not necessarily, according to this study. It very much depends on the precise nature of the operation; where and how are soldiers deployed, and whether they can respect international principles designed to mitigate harm to civilians. There are occasions, albeit not many, where soldiers can pursue criminal elements without threatening the surrounding population. That scenario will be discussed using Mexico as a case study.

\section{The Argument Against Military Use for Public Security}

The common wisdom among scholars has been to avoid reintroducing the military into internal security at all costs; that to do so would be to invite harm to citizens, whether intentional or unintentional. Militaries are normally organized for and trained in the use of maximum force, against a perceived enemy. ${ }^{4}$ This is what militaries do. But when security forces operate within densely populated urban areas where thousands of innocent civilians are in close proximity, the use of uninhibited violence can easily put those citizens in harm's way. Moreover, if maintaining public security and deterring crime is the mission, then those security forces must treat the public not as an enemy force, but as collaborators. It is the public that inevitably has information on who the criminals are, and to secure that information, security forces must gain its trust, much as police are supposed to do. Trained to take orders from above, not to interact with citizens from below, armed forces have a hard time adjusting to police-like work. Wittingly or unwittingly, they threaten the very citizens they depend on to provide intelligence on suspected criminals.

Moreover, if and when force must be used in an urban setting, it has to be used judiciously, conforming to international standards of restraint requiring calibrated, gradational and deferred violence. Force should be used only when necessary, and in proportion to the threat encountered. The obvious solution is to re-train the military. That is possible, but changes like these can be difficult because it demands that soldiers make the mental adjustment from the aggressive war-fighting practices they are accustomed to, to the less prestigious, more unfamiliar, controlled peacetime practices of law enforcement. ${ }^{5}$ Soldiers commonly find police-work to be demeaning, never associating it with

\footnotetext{
${ }^{4}$ LuTterbeck, D., "Between Police and Military: The New Security Agenda and the Rise of Gendarmeries", Cooperation and Conflict, vol. 39, núm. 1; McDavid, H., "Transformation vs. Amalgamation", Security and Defense Studies Review, vol. 7, núm. 3. Disponible en: http://www.ndu.edu/chds/

${ }^{5}$ Reed, B. J. \& Segal, D. R., "The Impact of Multiple Deployments on Soldiers' Peacekeeping Attitudes, Morale, and Retention", Armed Forces \& Society, vol. 27, núm. 1.
} 
promotional or salary rewards. They may resent their assignments, believing their time would be better spent preparing for combat. ${ }^{6}$ They may make their compliance contingent on government concessions or side payments. In short, they may not fully cooperate with their political overseers.

Still making the transition from combat to constable is doable, but requires a high degree of discipline, adjustment and versatility; while some militaries are up to the task, most are not. ${ }^{7}$ The failure to adapt can have harmful consequences. There is evidence that the military has been guilty of human rights violations while conducting internal, public security operations. Investigations conducted by respected NGos detail patterns of abuse at the hands of army units in Brazil, Mexico, Colombia, Central America, Peru, and elsewhere. ${ }^{8}$ A recent study finds that the Attorney General's office in Mexico launched 505 criminal investigations into human rights crimes allegedly committed by soldiers, between 2012-2016, including torture, enforced disappearances, homicide, extortion, and abuse of authority. ${ }^{9}$

\section{Disaggregating the Security Threat}

Consequently, should there be a wholesale ban on military internal public security operations? The short answer is no, because it depends on circumstances. It depends on what specific kind of operation we are speaking of, and what the nature of the threat is. Asking whether the armed forces should be immersed in internal security issues is the wrong question because it is too general, glossing over important distinctions regarding security risks to state and society. The need to involve the military, along with the potential risks associated with it,

\footnotetext{
${ }^{6}$ Surveys of peacekeepers from a variety of countries who are deployed to non-combat, policing operations find that they will do the job, but with reservations. They question just how appropriate it is and whether it is good for their careers in the long run. By large margins, peacekeepers have found the work to be boring. REED, B. J. \& SEGAL, D. R., "The Impact of Multiple Deployments on Soldiers' Peacekeeping Attitudes, Morale, and Retention", Armed Forces Et Society, vol. 27, núm. 1.

${ }^{7}$ Research by Campbell \&t Campbell found that the transition to policing is challenging because soldiers are told to absorb more convoluted rules of engagement that require considerable discretion and judgment, along with communicative skills (persuasion, negotiation) they are not at all accustomed to learning. Compounding the difficulty is that the constabulary job is perceived to be less compelling and prestigious, because it is less exciting and not essential for the protection of national security.

${ }^{8}$ Human Rights Watch, "Ni seguridad ni derechos: Ejecuciones, desapariciones y tortura en la 'guerra contra el narcotráfico' de México", Human Rights Watch. Disponible en: www.hrw.org/sites/default/files/reports/mexico1111spwebwcover.pdf

${ }^{9}$ Suarez-Enriouez, XImena, Overlooking Justice: Human Rights Violations Committed by Mexican Soldiers are Met with Impunity, Washington, Washington Office on Latin America, 2017, pp. 4, 16.
} 
are sure to vary, because internal security itself is multi-dimensional, as are the threats to it.

Answering this question demands that we disaggregate the internal security challenges facing some nations of Latin America. There is a geographical dimension to security responses. Population centers are not always at risk when challengers appear on the scene. It depends to what extent insurgents, criminals, and state security forces interface with the public, and how they interface with the public. Generally speaking, activities that take place in rural or remote regions pose fewer problems for non-combatants. Cultivation of illicit crops occurs almost entirely in rural areas that are sparsely populated. When crops are destroyed manually, it means the introduction of armed soldiers into poppy or marijuana farms that may or may not be heavily guarded. Where confrontations do occur between state security forces and narco-traffickers, who themselves have gotten in the business of cultivation or who are simply offering protection to farmers-there is a probability that non-combatants and non-criminals will be caught in the crossfire, but that probability is low, because these encounters occur in sparsely populated areas.

Drug interception poses a somewhat different and varied set of risks. Some exit points are along the coast, and naval and coast guard units can pursue speed boats or subs in open waters, avoiding contact with civilian populations, and minimizing risks. But many escape routes are on land, where the risks of drug interceptions hinge on where entry and exit points are located, how many there are, and how much of a nation's territory is traversed by traffickers to get from point A to point B. Military checkpoints along highways in more sparsely populated areas will not pose the same degree of risk as those within cities. Borderland operations in rural areas should also pose fewer problems, but where criminal organizations are transporting narcotics across metropolitan border areas, risks could be higher.

Within urban areas, it might be hypothesized that all military counterdrug operations are risky-too risky, because of the proximity of civilians. But even here too, a blanket prohibition on the armed forces may not make sense, where criminal organizations pose highly lethal threats to the State that cannot be adequately met by standard police forces. These are mid-level challengers, situated between full scale guerrilla organizations at the high end, and common criminals at the low end. ${ }^{10}$ Normally, to fight an insurgency, the state must

\footnotetext{
${ }^{10}$ The following section borrows from PIon-BerLin, D. \&t TrinkunaS, H., "Latin America's Growing Security Gap", Journal of Democracy, vol. 22, núm. 1; and PIon-BerLIN, D., "Neither Military nor Police: Facing Heterodox Security Challengers and Filling the Security Gap in Democratic Latin America", Democracy and Security, vol. 6, núm. 2.
} 
respond with military-led, counter-insurgency campaigns featuring heavily armed regiment or battalion sized units. Conversely, to contend with ordinary criminals, the state sends its police forces out to deter and investigate. It is in the middle where responses get more complicated. In that middle ground are situated the Drug Trafficking Organizations or DTo's, Transnational Criminal Organizations (тсо's) and criminal gangs. DTo's for example, are dangerous, sprawling conglomerates whose operations span multiple provinces and countries. Some can boast security forces that rival host country militaries in size and lethality. These mid-level organizations operate in and around densely populated areas, and compete with each other for control over illicit markets, drugs, trafficking routes, arms, contraband and neighborhoods. Thus, they can pose a formidable threat to the state, enough to warrant company or sometimes battalion-sized, military responses.

When countries confront these mid-level challengers, urban security is unlikely to be achieved without intervention by the armed forces. Only militaries can marshal the forces required to subdue midlevel challengers that threaten security. It has become readily apparent in recent years that police are no match for mid-level challengers. Outgunned, outnumbered and outmaneuvered by sophisticated and lethal criminal organizations, police have not been able to offer citizens the protection they need. On the contrary, they have often been complicit in criminal behavior, succumbing to bribery or intimidation. Hence, there can be no blanket prohibition on military internal security missions because that would leave powerful criminal elements to operate unimpeded, and place citizens at risk. In the case of Mexico for example, Raul Benitez Manuat makes this critical point:

Those who are critical of Mexico's strategy of using its armed forces and call for their removal from fighting organized crime propose an untenable solution because of the police forces' weakness and the absence of an alternative security agency that could replace the military. ${ }^{11}$

It is not just the fact that challengers are formidable. We also need to know what specific operations are required to confront them. What skills and assets are called upon to do the job? Does a military response mean conducting traditional police-styled work-- patrol, search and seizure, house arrests,

\footnotetext{
11 Benitez, Raul, "Mexico-Colombia: U.S. Assistance and the Fight Against Organized Crime", en Cynthia Arnson et al., One Goal, Two Struggles: Confronting Crime and Violence in Mexico and Colombia, Estados Unidos, Woodrow Wilson Center Reports on the Americas, 2014, p. 61.
} 
detention-which soldiers are ill-suited to, or does it mean an unconventional, urban, military-styled operation that may be more compatible with their training and skills? The military, it will be argued, has a different mind-set regarding police-like urban operations than it does operations that more closely conform to limited urban combat. It is the difference between activities which it cannot square with its organizational essence, its customary training and conditioning, from those it can. Some missions allow the military to perform in a way that is more consistent with its training, and possibly be more observant of international and national standards of conduct in pursuing criminal suspects. Those standards, to be detailed below, involve precautionary measures intended to reduce the chances for excessive force and collateral damage; that guide the military in minimizing hazards to the public even as it inflicts harm on the culpable.

To the extent that the military can incorporate these standards within its urban operations then it becomes more likely it can fight mid-level criminal elements without inflicting unnecessary harm to the public. Of course, there are no guarantees that militaries can make the necessary adjustments. To understand this, we have to consider that while they work in the same geographical areas, police and soldiers play different roles.

\section{Boundaries Between Police and Military Missions}

It is widely known that in the last two decades, the conceptual boundaries between domestic and external security have blurred, owing in large measure to the transformation of criminal agents. Illicit activities are increasingly coordinated, large in scope, and transnational or cross-border in nature. If criminal organizations regularly cross over territorial limits, then a security challenge may be neither purely domestic nor external; it could be both, thus blurring the line between defense and public security spheres. For example, drugs, human trafficking, contraband, and arms smuggling, are activities that take place across borders, and have repeatedly been priority items on the agenda at the bi-annual Defense Ministerials from 1995-2016. ${ }^{12}$

But it is one thing to say the line between the domestic and the external has blurred; it is another thing to say that actual police work and military tasks must necessarily converge. Some scholars do maintain that both the military and police have crossed the line, with police becoming more militarized and

\footnotetext{
12 "Conferencias de Ministros de Defensa de las Americas, Declarations for Each Conference, 1995-2014", Organización de Estados Americanos. Disponible en: http://www.oas.org/csh/spanish/docminist.asp
} 
soldiers becoming more police-like. P. Andreas and R. Price state: "The distinction between law enforcement and military missions breaks down, too; military tasks become increasingly domesticated and civilianized, and policing tasks become increasingly internationalized and militarized". ${ }^{13}$ But B. K. Greener-Barcham maintains that a blurring of domestic and international security spheres, does not automatically conflate police and military roles. While acknowledging that the expansion of the security concept may run the risk of "militarizing" it as well, he finds that in case of New Zealand, and the Solomon Islands, police and military roles were distinct and supportive. ${ }^{14}$ Safeguarding a division of labor between police and military conduct, actually helped the overall security effort. In this particular case, the police took the lead, actually assigning the armed forces its tasks. The armed forces created a more secure environment in which the police could operate. While there were problems of communication, and questions about what it meant for military to give way to police commanders, generally division of labor worked well. Thus, even with an expanded concept of security, and a transnational, cross-border reality to security, it is possible to maintain a division of labor between military and police activity.

Greener-Barcham's observations are important, because they leave open the possibility that the military could participate in internal security operations while confined to tasks that fit more comfortably with soldiering, albeit of an unconventional kind. This might mean avoiding the undesirable situation of forcing the military into traditional policing roles they are ill-suited for, find distasteful, and would rather avoid. The choice is not between traditional policing and traditional war-fighting. It is a choice between a conventional militarized operation and an unconventional one that is more finely tuned to cope with a densely populated urban setting, that is attentive to the risks, and specially designed to separate "enemy" targets from the general population. An urban, counter drug or counter crime mission, for example, can take on characteristics similar to army urban combat against terrorists, insurgents or paramilitary forces, and face similar challenges. The U.S. Army Field Manual for Urban Operations acknowledges the difficulties of fighting in cities:

\footnotetext{
${ }^{13}$ AndreAS, P. \& PRicE, R., "From War Fighting to Crime Fighting: Transforming the American National Security State", International Studies Review, vol. 3, núm. 3, p. 52.

${ }^{14}$ Greener-Barcham, B. K., "Crossing the Green or Blue Line? Exploring the Military-Police Divide", Small Wars and Insurgencies, vol. 18, núm. 1.
} 
Of all the environments in which to conduct operations, the urban environment confronts Army commanders with a combination of difficulties rarely found elsewhere. Its distinct characteristics result from an intricate topography and high population density. The topography's complexity stems from the man-made features and supporting infrastructure superimposed on the natural terrain. Hundreds, thousands, or millions of civilians may be near or intermingled with soldiers-friendly and enemy. This second factor, and the human dimension it represents, is potentially the most important and perplexing for commanders and their staffs to understand and evaluate." 15

The U. S. army's observation brings into sharp relief one of the principle challenges in the use of the military in densely populated zones: how to safely separate the enemy target from the civilian population. This speaks to one of the key rules regarding the use of force that is built into international human rights and humanitarian law, and un codes of behavior: $:^{16}$ this is the demand that an adversary be clearly identified, separated from civilians, that force only be directed at him, and that innocent civilians not be put at risk. This is the principle of distinction (also known as discrimination), and is perhaps the most critical ingredient for the armed forces to successfully prosecute a counter-crime operation humanely. The military has to be reasonably certain that a target is the enemy, in order to avoid collateral damage. Second it must be able to separate the target from the surrounding population in order to not inadvertently inflict damage on the innocent.

This is a stiff requirement for military action. It demands circumspection and careful intelligence gathering. The question is under what conditions, if any, would the military be able to comply with these constraints? Here, we argue that there must be some minimal, military nature to the mission; it cannot be so completely divorced from what the military is trained to do, and wants to do. It cannot force soldiers into a police mold, because there is a fundamental disconnect between policing and military professionalism. To make the point we will consider the differences between military police patrols $v$ s. high value

\footnotetext{
${ }^{15}$ United States Army, "U.S. Army Field Manual No. 3-06 Urban Operations", United States Army. Disponible en: http:// armypubs.army.mil/doctrine/DR_pubs/dr_a/pdf/fm3_06.pdf

${ }^{16}$ The un Code of Conduct for Law Enforcement stipulates that force be used with restraint and "only when strictly necessary". United Nations, "The un Code of Conduct for Law Enforcement. General Assembly Resolution 34/169", United Nations, 17 de diciembre. Disponible en: http://www1.umn.edu/humanrts/instree/i1ccleo.htm
} 
targeted operations (нVTо) -those conducted against the leaders of drug syndicates. We will draw on the Mexican case as an example.

\section{The Mexican Case: Military Police Patrols vs. High Value Targeted Operations}

Police patrols are those operations where army and navy units engage in citywide crime sweeps. Officers, split into groups of two or three, patrol block by block either alone or alongside of the police in search of lower level criminal suspects. These operations may involve house to house searches, questioning occupants, seizing possessions, making arrests and detaining and interrogating suspects. High value targeted operations are military-styled engagements, designed to capture or kill known, high profile, drug trafficking leaders. They rely on formed units, and pursue with precision, individuals already identified as criminal suspects.

On the one hand, there are similarities between the two kinds of operations. First and foremost, they take place mostly in cities. Cartel members, whether high or low-level operators, can and do blend into the population. Even when they make their presence known, they are not easy targets, since thousands, perhaps tens of thousands of innocent civilians are situated close by. Second, because of the urban geography, soldiers are operating in close quarters, and in proximity to places of residence and business. Third, they come heavily armed, and the chances that innocent civilians could be inadvertently harmed are ever present. This is especially so since cartel leaders are surrounded by men equipped with an arsenal of high powered rifles, submachine guns, even grenades. That means the military must come equally prepared, and the lethality of the confrontation could get quickly out of hand, jeopardizing all those in the immediate area.

Fourth, soldiers make direct, intentional contact with the public. In the days leading up to an assault, they may be gathering information from neighbors. The day of the assault, they may have to request that residents quickly vacate their homes, and then direct them to secure places where they are kept under guard. If public contact is, as has been suggested, a huge risk factor for the armed forces, if soldiers have difficulties acclimating themselves to an environment where they must calmly and patiently interact with the population, then certainly high value targeted operations should be prone to serious missteps.

On the other hand, the differences with urban patrols are sizeable, and those differences help explain how targeted operations can be carried out with 
substantially less risk to the unarmed population than can police patrols. When military personnel are asked to do law enforcement work in urban patrols designed to hunt for criminal elements, they have to make difficult, unrewarding behavioral adjustments that ultimately prove counter-productive. In police patrols, the military (army and navy) is often sent out in small teams, paired up with policemen in search of lower-level criminals or operating on their own. They rarely come prepared with solid intelligence, relying instead on anonymous tips. Generally, they do not have a lot of information to go on, and so they often are not sure who are reliable suspects and who are innocent. And yet, they are under pressure from their superiors to produce results. They are given powers of search, seizure and arrest, but not given adequate training in how to use those powers cautiously and prudently. In the face of uncertainty, under pressure to find criminals, and with inadequate training, they are quick to accuse, assault and apprehend arbitrarily, without evidence or warrants. Rather than taking the time to find credible leads, they lump all those within proximity to the target as hostile suspects. That perception leads to callous militarized crime sweeps that fail to make careful distinctions that might have saved lives. The military, in other words, respond poorly, rashly, violently, and inevitably end up violating rules of necessity, rationality, proportionality and discrimination.

Moreover, the Mexican army and navy do not immediately turn suspects over to the police for further questioning, because they do not trust the police to do their jobs. Thus, they prefer to hold onto the suspects, hauling them off to a military installation for detention and questioning. ${ }^{17}$ But without experience in methods of humane interrogation, and anxious to extract confessions, they resort to excesses, such as torture and other forms of cruel treatment. Sometimes, those suspects would never resurface, their names filed under 'disappeared'. These scenarios match many others in terms of chosen methods of operation, suggesting that the abuse was not the work of renegade officers but rather sanctioned by higher ups, as part of an authorized operation. ${ }^{18}$

By contrast, the military appear to be able to conduct high value targeted operations more effectively and humanely. First of all, identification of suspects is easier in high value target operations. Cartel leaders are public figures. While they may move in the shadows, they would not have climbed to the top of their organizations in complete obscurity. Their names are known, and at

\footnotetext{
${ }^{17}$ Human Rights Watch, "Mexico's Disappeared: The Enduring Cost of a Crisis Ignored. New York: Human Rights Watch", Human Rights Watch. Disponible en: http://www.hrw.org/reports/2013/02/20/

${ }^{18}$ Human Rights Watch, "Mexico's Disappeared: The Enduring Cost of a Crisis Ignored. New York: Human Rights Watch", Human Rights Watch. Disponible en: http://www.hrw.org/reports/2013/02/20/
} 
times, so are their faces. There may or may not be photographic evidence, but the army and navy almost always know who they are looking for. The military on HVTO do not have to subject drug leaders to questioning in order to determine whether they do in fact warrant suspicion and arrest. They are going after cartel leaders who are presumed and usually proven criminals. They have often served time, they have criminal track records, and if not, they have notorious reputations. They are commonly thought to having sanctioned countless murders and massacres, and indeed, would not have risen to the top of their syndicates without having done so.

Hence, there is little doubt about their culpability, and that easily earns them the label 'enemy.' This is key, because it resonates with the armed forces raison d'être; they are trained to hunt down enemy forces. And because they can pin-point the target, they can also make a clear separation between the 'bad guys' and the 'good guys', following the rule of discrimination. In short, targeted high value operations of this sort can be designed and framed in ways which fit more comfortably with missions soldiers are cut out for.

If the military knows who it is they are after, finding out where they are is a more complicated challenge. Obviously, the most wanted have been adept at avoiding detection and capture for some time, which compels careful intelligence gathering and reconnaissance work on the part of the security forces and agencies. Intercepting cell phone communications, wiretapping phone lines, finding informants, and then studying the movements and habits of a criminal are all part of a long, methodical, sometimes painstaking process of discovery. Thus, it is almost always the case that dramatic kingpin captures, and assassinations have been preceded by weeks if not months of careful planning, enabling the armed forces to ultimately pin-point their target. Drug lord assaults can, in other words, carefully discriminate between violent offenders of interest, and non-violent bystanders, placing them in stark contrast to the indiscriminate and ad hoc, military police-like patrols.

The armed forces normally pursue drug leaders within cohesive units. They have trained together, and now they can operate together. This is in contrast to police patrols where soldiers may have to split up from their units into teams of 2 or 3 . The units that pursue cartel leaders are normally designed and specially trained for purposes of that kind. ${ }^{19}$ The Mexican navy, for example, has deployed a marine infantry and parachutist battalion created in 1992 as an

\footnotetext{
19 Infanteria de Marina, "La Elite de las fFAa Mexicanas y fes", Defensa, 2013. Disponible en: http://www.defensa.com/ index.php?option=com_contentEtview $=$ articlectid $=10173$
} 
elite force held in reserve for high impact counter-narcotic expeditions. They have also deployed special forces that go by the names of Fuerzas Especiales del Golfo (Fesgo) and Fuerzas Especiales del Pacifico (Fespa). Formed in 2001, they have been specifically trained in urban combat, building assaults, and closed, indoor confrontations. In addition, thousands of Mexican soldiers have trained in the United States. Between 2006 and 2014, over 16000 Mexican troops completed counter-narcotics programs at U. S. military institutions, second only to Colombia. ${ }^{20}$ Among the courses taken were asymmetrical conflict, counter-drug operations, urban operations, and counter intelligence. ${ }^{21}$

Much of the training was overseen by the U. S. Northern Command (US-Northcom), which insists that it adheres to human rights standards. According to law, it must. The 1997 Leahy amendment demands that foreign soldiers they associate with not be involved in any human rights abuses. ${ }^{22}$ By contrast, army and navy personnel sent on joint patrols with the police were not specialized, nor adequately trained. I do not know of any program that has trained the Mexican military in pure police tactics.

Why do these differences between police patrols and HVTO matter? Soldiers should, in theory, be able to better observe the international rules regarding use of force. The military can treat a high value target operation as if it was a military mission. Mindful of who they are going after, the military forces assigned to targeted drug lords can direct their explosive force at the enemy -the crime leader, not his neighbors. They have no need to treat those in the vicinity as hostile or suspicious; they are neither. They can pin point their target and in that manner, avoid a "dirty" operation that in advertently places others in harm's way. In other words, in making the mental and physical separation between the enemy and the innocent, they can abide by the international principle of distinction. Second, based on actual intelligence, not rumors and hearsay, they have identified the culpable party, and thus can move in to make the arrest with great confidence. They can call for the drug lord's arrest, and if he abides, can conduct the operation without any resort to violence. Oftentimes, that occurs because of the element of surprise. The cartel leader is caught off

\footnotetext{
20 "About Data Resources Publications Blog Press", Security Assistance Monitor. Disponible en: http://www.securityassistance.org/data/country/trainee/country/2006/2014/is_drug/Latin\%20America\%20and\%20the\%20Caribbean ${ }^{21}$ ConkoY, B., "US Military Training of Mexican Security Forces Continues", The Narcosphere, 3 de diciembre. Disponible en: http://narcosphere.narconews.com/notebook/bill-conroy/2014/12/us-military-s-training-mexican-security-forces-continues-human-rights-

${ }^{22}$ Conroy, B., "US Military Training of Mexican Security Forces Continues", The Narcosphere, 3 de diciembre. Disponible en: http://narcosphere.narconews.com/notebook/bill-conroy/2014/12/us-military-s-training-mexican-security-forces-continues-human-rights-
} 
guard, without his enforcers at his side. ${ }^{23}$ When violence is used, the principle of necessity can be followed. The military will use force only after calling for the cartel leader's surrender. Should he refuse and instead take up arms, then the military can respond accordingly.

Preliminary empirical inquiries indicate that in Mexico, the distinction between police patrols and high value targeted operations matters in terms of protecting the lives of innocent civilians. There have been countless complaints registered with the Mexican National Commission on Human Rights against armed forces personnel since 2006. A small percentage of these complaints have been thoroughly investigated by the Commission, which then issues reports. Based on a reading of a sample of those reports, it is evident that in each and every case, human rights violations occur during military patrols or check points. There is no indication that abuses occurred during нVTo. ${ }^{24}$ To the contrary, based on a review of newspaper accounts of HVTo there does not seem to be any civilian casualties that occurred during those operations. ${ }^{25}$

\section{Conclusion}

This article has asserted that there are occasions when countries must call upon the armed forces to deploy inside their borders to protect public security. When mid-level challengers threaten security, police are often unable to respond effectively. It may take the armed forces to step in to assist in eliminating or containing the threat. When they do, they must follow rules of engagement designed to minimize harm to civilian, non-criminal populations. Can they comply? This study has argued in the affirmative, in certain situations, if they can search for criminals within the framework of an unconventional, military-like operation. There must be compatibility between the demands of the operation, the military's skill set, its professional inclinations, and the ability to conform to international principles of engagement in urban-styled operations. If, on the other hand, soldiers are forced to do policing, they have a more difficult time coping, and may break with standards of conduct designed to protect civilians.

\footnotetext{
${ }^{23}$ In fact, based on my own analysis of 77 HVTo conducted in Mexico between 2007-2012, 70 (90\%) resulted in criminal apprehensions without death, and only $7(10 \%)$ resulted in the killing of the cartel leaders or his sicarios. There were no reported civilian casualties. See PIon-BerLIN, D., "A Tale of Two Missions: Mexican Military Police Patrols vs. High Value Targeted Operations", Armed Forces \& Society, vol. 43, núm. 1.

24 "Recomendaciones", Comisión Nacional de los Derechos Humanos. Disponible en: http://www.cndh.org.mx/Recomendaciones

${ }^{25} \mathrm{~A}$ full accounting of this empirical research can be found at Pion-Berlin, D., "A Tale of Two Missions...", op. cit.
} 


\section{References}

“About Data Resources Publications Blog Press”, Security Assistance Monitor. Disponible en: http://www.securityassistance.org/data/country/trainee/country/ 2006/2014/is_drug/Latin\%20America\%20and\%20the\%20Caribbean

Andreas, P. Ct Price, R., "From War Fighting to Crime Fighting: Transforming the American National Security State”, International Studies Review, vol. 3, núm. 3, p. 52.

Benitez, Raul, "Mexico-Colombia: U.S. Assistance and the Fight Against Organized Crime", en Cynthia Arnson et al., One Goal, Two Struggles: Confronting Crime and Violence in Mexico and Colombia, Estados Unidos, Woodrow Wilson Center Reports on the Americas, 2014.

"Comparative Atlas of Defense in Latin America and the Caribbean", Red de Seguridad $y$ Defensa de América Latina, 2014. Disponible en: http://www.resdal.org/

"Conferencias de Ministros de Defensa de las Americas, Declarations for Each Conference, 1995-2014", Organización de Estados Americanos. Disponible en: http:// www.oas.org/csh/spanish/docminist.asp

Conroy, B., "US Military Training of Mexican Security Forces Continues", The Narcosphere, 3 de diciembre. Disponible en: http://narcosphere.narconews.com/ notebook/bill-conroy/2014/12/us-military-s-training-mexican-securityforces-continues-human-rights-

Greener-Barcham, B. K., "Crossing the Green or Blue Line? Exploring the Military-Police Divide", Small Wars and Insurgencies, vol. 18, núm. 1.

Human Rights Watch, “Mexico's Disappeared: The Enduring Cost of a Crisis Ignored. New York: Human Rights Watch", Human Rights Watch. Disponible en: http:// www.hrw.org/reports/2013/02/20/

Human Rights Watch, "Ni seguridad ni derechos: Ejecuciones, desapariciones y tortura en la 'guerra contra el narcotráfico' de México", Human Rights Watch. Disponible en: www.hrw.org/sites/default/files/reports/mexico1111spwebwcover.pdf

InfanteriadeMarina, “LaElitedelasfFaAmexicanasyfes”,Defensa,2013.Disponibleen:http:// www.defensa.com/index.php?option=com_contentEtview=articlectid=10173

Lutterbeck, D., "Between Police and Military: The New Security Agenda and the Rise of Gendarmeries", Cooperation and Conflict, vol. 39, núm. 1.

McDavid, H., "Transformation vs. Amalgamation", Security and Defense Studies Review, vol. 7, núm. 3. Disponible en: http://www.ndu.edu/chds/

Pion-Berlin, D., "A Tale of Two Missions: Mexican Military Police Patrols $v s$. High Value Targeted Operations", Armed Forces \&t Society, vol. 43, núm. 1.

Pion-Berlin, D. \& Trinkunas, H., "Latin America's Growing Security Gap”, Journal of Democracy, vol. 22, núm. 1.

Pion-Berlin, D., "Neither Military nor Police: Facing Heterodox Security Challengers and Filling the Security Gap in Democratic Latin America", Democracy and Security, vol. 6, núm. 2. 
“Recomendaciones”, Comisión Nacional de los Derechos Humanos. Disponible en: http://www.cndh.org.mx/Recomendaciones

ReEd, B. J. \& SEgAL, D. R., “The Impact of Multiple Deployments on Soldiers' Peacekeeping Attitudes, Morale, and Retention”, Armed Forces \& Society, vol. 27, núm. 1.

SuAREZ-EnRIQuez, XimenA, Overlooking Justice: Human Rights Violations Committed by Mexican Soldiers are Met with Impunity, Washington, Washington Office on Latin America, 2017.

United Nations, "The un Code of Conduct for Law Enforcement. General Assembly Resolution 34/169”, United Nations, 17 de diciembre. Disponible en: http://www 1. umn.edu/humanrts/instree/i1ccleo.htm 